\title{
Fatty acid composition of the post larval daubed shanny (Leptoclinus maculatus) during the polar night
}

Svetlana N. Pekkoeva ${ }^{1}$, Svetlana A. Murzina ${ }^{1}$, Zinaida A. Nefedova ${ }^{1}$, Stig Falk-Petersen², Jørgen Berge ${ }^{3,4,5}$, Ole J.

\section{Abstract}

Recent discoveries of high levels of biological activity in the Arctic marine ecosystems during the polar night raise questions regarding the ecophysiology of the pelagic postlarval daubed shanny Leptoclinus maculatus. Of special interest in the composition of the lipid sac - a unique feature not found in other Arctic fishes. Analysis of the fatty acid content of major classes of lipids as membrane - total phospholipids (PL) and storage - triacylglycerols (TAG) in the different postlarvae stages during the polar night is presented in this work for the first time. A high levels of monounsaturated fatty acids (MUFA) (70\%-74\% of the total fatty acids (FA) of TAG) was found in the TAG of the L3-L4 postlarvae stages, among which 20:1n-9 (28\%) and 22:1n-11 (27\%-29\%) FA are trophic biomarkers of the zooplankton Calanus spp. Among the polyunsaturated FA (PUFA) the n-3 FA dominated (22:6n-3 - in the PL, and 18:4n-3 - in the TAG). A decrease in the SFA and an increase in the MUFA in the structural PL during the transition from the postlarval to the demersal stage was observed. Our analyses of the FA composition of the lipid sac suggest that it continues to actively hunt for its preferred prey item Calanus spp. during the polar night.

Keywords: Leptoclinus maculatus, lipid sac, fatty acids, lipid classes, adaptation, polar night, Arctic, Spitsbergen

\section{Introduction}

Pelagic high latitudes marine animals are known to store lipids as an adaptive strategy to environmental changes on different time scales (Falk-Petersen et al. 2004, 2009). The daubed shanny, Leptoclinus maculatus (Fries, 1838), is a common demersal fish in the Arctic (Makushok 1979; Meyer Ottesen et al. 2014). The life history involves a pelagic juvenile stage that last from three to five years (Meyer Ottesen et al. 2011), and its body (dry weight) consists of 40\% lipids (Falk-Petersen et al. 1986; Murzina 2010; Pekkoeva et al. 2017a; Meyer Ottesen et al. 2018). The abdominal part of the body of the pelagic postlarvae contains a morphophysiological structure hereafter referred to as a "lipid sac" (Falk-Petersen et al. 1986; Murzina 2010), which stores lipids as triacylglycerols.

The lipid sac is considered an adaptation for growth and development in an environment with strong seasonal changes in the food supply (Murzina 2010; Pekkoeva et al. 2017a, b). The lipid sac begins at the pectoral

Svetlana N. Pekkoeva

e-mail: pek-svetlana@mail.ru; +79535266012

${ }^{1}$ Institute of Biology of the Karelian Research Centre of the Russian Academy of Sciences, Petrozavodsk, Russia;

${ }^{2}$ Akvaplan-niva AS, Fram Centre, N-9296, Tromsø, Norway;

${ }^{3}$ UiT The Arctic University of Norway, Department of Arctic and Marine Biology, Tromsø, N-9037, Norway;

${ }^{4}$ The University Centre in Svalbard, N-9171 Longyearbyen, Norway;

${ }^{5}$ Norwegian University of Science and Technology, Centre for Autonomous Marine Operations and Systems, Tromsø, Norway. 
fins and runs to the anus. It is marked by a series of melanophores and consists of large, closely packed lipid vacuoles surrounded by a simple membrane (Falk-Petersen et al. 1986; Murzina 2010; Meyer Ottesen et al. 2011). A specific feature of the lipid sac of the daubed shanny is that its storage lipids are homogenous and do not accumulates in fat cells (adipocytes) as they do in adipose tissue (Falk-Petersen et al. 1986; Murzina 2010). For example, the adult Antarctic notothenioid fish Pleuragramma antarcticum has intermuscular lipid structures, which are lipid sacs that consist of several white adipocytes with a large lipid droplet, and whose key function is to maintain the neutral buoyancy of the fish in the absence of a swim bladder (Eastman and DeVries 1989).

The primary function of the lipid sac in the daubed shanny is considered to be energy storage; however, lipids also contribute to buoyancy (Falk-Petersen et al. 1986; Murzina 2010). The melanophores and light refraction through the lipid droplets in the pelagic larvae are believed to make them inconspicuous to predators (Falk-Petersen et al. 1986; Pekkoeva et al. 2017a). This provisory organ is formed in the postlarvae stage of the daubed shanny as they begin feeding. Its size and lipid content increase during the prolonged pelagic larval development (three to five years). The lipid sac is resorbed at the demersal juvenile stage (Meyer Ottesen et al. 2011). To date, lipid sacs have only been found in Arctic-dwelling fish of the family Stichaeidae (Falk-Petersen et al. 1986; Murzina 2010; Meyer Ottesen et al. 2011).

Leptoclinus maculatus post larvae, feeding mainly on Calanus spp., has an important role in the Arctic food web transferring high energy lipids to fish, sea birds and mammals (Barrett 2002; Hovde et al. 2002; Weslawski et al. 2006; Labansen et al. 2007). Recent studies have revealed high biological activity in the Arctic marine ecosystems during the polar night, despite the absence of visible light (Berge et al. 2015a, b). Daubed shanny post larvae, are a visual predator, believed to feed intensely on Calanus spp. copepod during summer and winter, to sustain them during the polar night with little or no food. In this paper, we present new data, on the fatty acid composition of phospholipids as structural lipid type and triacylglycerols providing energy from the unique lipid sac. The data are discussed in relation to the trophic possession, development and function of the bio-membrane during the polar night.

\section{Materials and methods}

Sampling

Daubed shanny larvae were collected during the polar night, 14-20 January 2014, from the research vessel Helmer Hanssen in fjords on west coast Svalbard $\left(79^{\circ} \mathrm{N}\right)$ with MIK net, pelagic- and bottom trawl. The sea temperature was between 0.6 and $1,9^{\circ} \mathrm{C}$ and salinity approx. 34.8 psu. (Table 1)

The stages of development were defined according to the classification of Meyer Ottesen et al. (2011). The five developmental stages (L1, L2, L3, L4, and L5) were identified based on the morphological and physiological characteristics such as size, weight, colour and body pigmentation, as well as conditions of the lipid sac. During the expedition, the L4* development stage was distinguished from the L4 and L5 stages by a darker body colour, larger body and gills and the presence of a large lipid sac.

65

\section{Lipid extraction}

The lipid sacs of the L3, L4, and L4* development stages was dissected out from the fresh fish as soon as possible in cold conditions (Fig 1, Table 2). To prevent degradation of complex lipids, samples were fixed in 96\% 
total lipid was extracted from the samples stored in chloroform/methanol (2:1, v/v) by the method of Folch et al. (1957) and further threated as outlined by Murzina et al. (2013). Thin-layer chromatography (TLC).

TLC was used for qualitative and quantitative determination of individual lipid classes as total phospholipids (PL), triacylglycerols (TAG), cholesterol (Chol) and cholesterols (Chol esters). Fractionation of total lipids was performed on ultrapure glass TLC Silica gel $60 \mathrm{~F}_{254}$ Premium Purity plates (Merck, Germany). The petroleum ether-diethyl ether-acetic acid (90:10:1 by volume) solvent system was used. After drying, the chromatogram was developed in iodine vapor.

Certain lipids (PL, TAG, Chol ester and wax esters) were quantified using the hydroxamate method that was modified by (Sidorov et al. 1972), which involves the formation of dark-brown complexes of trivalent iron ions with hydroxamic acid through ester bonding between the lipids and hydroxylamine (Walsh et al. 1965). The stain intensity was measured using a spectrophotometer (SF-2000, OKB "Spectr", Russia) at a wavelength of $540 \mathrm{~nm}$. The quantitative determination of Chol was determined based on the method described by (Engelbrecht et al. 1974) using trichloroacetic iron dissolved in perchloric acid. The stain intensity was measured using a spectrophotometer at a wavelength of $550 \mathrm{~nm}$. Lipid classes were identified according to the standards of the respective studied components (Sigma-Aldrich, USA; Avanti Polar Lipids, Inc., USA) taking into account the correspondence of the Rf values.

87

Gas chromatography

TAG and PL was analysed by gas chromatography. Material for fatty acid methylation of PL and TAG were scraped (spots) from the TLC plates. $0.1 \mathrm{~mL}$ of a solution containing $20 \mathrm{mg} / 10 \mathrm{~mL}$ (behenic FA, C22:0) (Sigma Aldrich, USA) in methanol was added as internal standard. Fatty acid methyl esters (FAME) were identified using a gas chromatograph "Chromatec-Crystal-5000.2" (Chromatec, Russia), with a flame ionization detector and a capillary gas chromatographic column Zebron ZB-FFAP (Phenomenex, USA).

The mobile phase was nitrogen. The separation mode was isothermal, the thermostat temperature of the columns was $200^{\circ} \mathrm{C}$, the temperature of the detector was $250{ }^{\circ} \mathrm{C}$, and the temperature of the evaporator was $240{ }^{\circ} \mathrm{C}$. Under these conditions, the methyl esters of fatty acids were divided according to their number of carbon atoms and double bonds. Chromatec-Analytik-5000.2 software (Chromatec, Russia) was used for recording and integrating the data. Fatty acids methyl esters were identified with standard mixtures of Supelco 37 Components FAME Mix (Sigma Aldrich, USA) and the lengths of the carbon chain and table constants were compared according Jamieson (Jamieson 1975). The research was carried out using the facilities of the Equipment Sharing Centre of the KarRC of RAS.

The results are given as means \pm SE (standard error). Differences between means of total lipids, lipidclasses and fatty acids in the lipid sac were analysed by ANOVA (one-way) (ANOVA_F_1,25, $p=0,0250$ ).

104 Differences were considered statistically significant at $p \leq 0.05$. A normal distribution was confirmed by (ShapiroWilk's W test, $p>0.05)$.

\section{Results}

107 Fatty acid composition of triacylglycerols (storage lipids)

108 We observed large and continuous increases in size (Pekkoeva et al. 2018), volume (Figure 1, Table 1) and 109 lipid content of the lipid sac during the development from L1 to L5 stages of development. The composition of 110 TAG in the lipid sac of the daubed shanny at the L3, L4, and L4* developmental stages was dominated by the 
111 MUFA, with 71\%-74\% of the total FA. Saturated (SFA) and the PUFA contributed much smaller amounts ( Table

112 3). The dominant TAG FAs were the $20: 1 n-9$ (27.5\%-28.2\% of the total FA) and 22:1n-11 (26.9\%-29.3\% of the

113 total FA). In total, the 20:1n-9 and 22:1n-11 FA accounted for nearly $60 \%$ of the TAG. Among the PUFA, 18:4n-3,

114 20:5n-3, 22:6n-3 FAs were recorded, but their level was approximately equal or lower than 2\% of the total FA. No

115 significant differences in the content of these FA among ontogenetic stages were found. The SFA featuring high

116 levels were 14:0 and 16:0 FA (up to 7\%-8\%).

118 Fatty acid composition of phospholipids (membrane lipids)

119 The FA composition of phospholipids (PL) at stage L3 showed a prevalence of SFA (58.1\% of the total 120 FA), whereas at stages L4 and L4*, the MUFA were dominant. A decrease $(p \leq 0.05)$ in the SFA content (from $12158.1 \%$ to $25.9 \%$ of the total FA) and a rise ( $p \leq 0.05$ ) in the MUFA content (from $26.3 \%$ to $60.6 \%$ of the total FA) by 122 stage L4* was observed. Among the MUFA in the PL, the 20:1n-9 and 22:1n-11 FA were prevalent, and their levels 123 rose $(p \leq 0.05)$ from $9.7 \%$ to $24.8 \%$ of the total FA and from $7.7 \%$ to $20.4 \%$ of the total FA by stage L4*, 124 respectively. Remarkably, the content of the palmitoleic 16:1n-7 FA was higher in the TAG (6.2\%-7.1\% of the total 125 FA) compared to the PL (2.0\%-5.0\% of the total FA). The prevalent PUFA in the lipid sac of the daubed shanny at 126 stages L3, L4, and L4* were FA of the $\mathrm{n}-3$ class (4.6\%-7.7\% of the total FA), primarily attributed to the 22:6n-3 127 and 20:5n-3 FA. The 16:0/18:1n-9 ratio in the PL was 2.4-2.8, which is higher than in the TAG (1.6-1.7). In the n-6 128 class, linoleic acid 18:2n-6 prevailed in both the PL and TAG.

\section{Discussion}

130 The lipid sac is a provisory organ in daubed shanny larvae, where the substantial amounts of the TAG are 131 stored (up to 68 \% dry weight), while PL, cholesterol esters and cholesterol constitute lower amounts (Falk-Petersen 132 et al. 1896; Murzina 2010; Pekkoeva et al. 2017a) (Table 2). TAG in the lipid sac of the daubed shanny postlarvae at 133 all investigated stages (i.e., L3, L4, and L4*) demonstrated the MUFA as the prevailing FA (71\%-74\% of the total 134 FA in TAG) (Table 3). Leptoclinus maculatus has an important role as an intermediate in the Arctic trophic chains, 135 where it simultaneously acts as a predator and prey.

136 The MUFA is a main component of storage lipids (Tocher et al. 1985; Tocher 2003), and their structure 137 makes them energetically important for maintaining the metabolic needs of the organism; therefore, MUFA are 138 mainly used as sources of energy (Lloret et al. 2014). The FA composition of the lipids in fish is strongly dependent 139 on the fatty acid composition of their diet (Dalsgaard et al. 2003; Tocher 2003, 2010; Arts and Kohler 2009; 140 Nemova et al. 2015). In Arctic ecosystems Calanus spp. species are the most important herbivorous zooplankter 141 (Søreide et al. 2006; Mayzaud et al. 2015) and are the main food item for many Arctic pelagic fish, including the 142 daubed shanny post larvae. Species of the zooplankton Calanus also have a lipid sac, where lipids are stored (up to $14370 \%$ dry weight) primarily as wax esters. Calanus copepods can de novo synthesize 20:1n-9 and 22:1n-11 FA, 144 which are reliable trophic biomarkers (Dalsgaard et al. 2003; Sargent and Henderson 1986; Kattner and Hagen 145 1995). The dominant MUFA in Calanus glacialis, C. finmarchicus, and C. hyperboreus are 20:1n-9, 22:1n-11, and 146 16:1n-7 FA (Lee et al. 2006; Mayzaud et al. 2015), which are transferred up the food chain to fish, seabirds, and 147 mammals (Falk-Petersen et al. 2007). Wax esters from copepods enter the body of fish during feeding and converted 148 into membrane and reserve lipids). A structure like the lipid sac in polar animals are believed to be an adaptation to 149 the cold environment and the seasonal variations in food availability. Daubed shanny is well adapted for 150 reproduction and development in northern latitudes (Falk-Petersen et al. 1986; Meyer Ottesen et al. 2011, 2014; 151 Murzina et al. 2012, 2013a, b). Some studies (Mecklenburg et al. 2011) have shown the expansion of its habitat in 
the seas of the Arctic Ocean. The Kongsfjorden-Krossfjorden fjord system is particularly suitable for studies of effects of climate changes on ecosystems because it lies adjacent to both Arctic and Atlantic water masses (Hop et al. 2006). The proportions of copepods, the boreal C. finmarchicus and local Arctic C. glacialis (which the daubed shanny postlarvae actively feeding on) are varying seasonally and annually in Kongsfjorden depending on the timing and volume of Atlantic and Arctic water mass intrusions (Kwasniewski et al. 2003). Leptoclinus maculatus was identified as an indicator species along with other fish from the Arctic region for studying variations in the structure of ecosystems of high latitudes under climatic changes (Swanburg et al. 2015).

In earlier studies (Pekkoeva et al. 2017a), we observed an increase in the content of 20:1n-9 and 22:1n-11 FA of the total lipids in the muscles of larvae of the L2 stage, likely in connection with the transition to a highenergy diet of Calanus spp. zooplankton from the phytoplankton-based diet at the L1 stage. These FA, which are derived from a Calanus diet, are mostly included in the TAG of the lipid sac (up to 28\%-29\% of the total FA) of L3, L4 and L4*. In this study, high amounts of 20:1n-9 and 22:1n-11 FA (up to 29\% of the total FA) were found among MUFA of the TAG. In comparison, the content of MUFA in the TAG of muscles of the postlarvae (L3-L4* stages) is lower (61\%-65\% vs 71\%-74\% of the total FA in TAG) due to $20: 1 \mathrm{n}-9$ and $22: 1 \mathrm{n}-11 \mathrm{FA}$ (22\%-25\% and 17\%-22\% respectively) (Pekkoeva et al. 2019). The level of 16:1n-7 FA in the TAG of the lipid sac of the daubed shanny postlarvae is within 6\%-7\% the total FA in the polar night, and 8\% in the autumn (Falk-Petersen et al. 1986). The 16:1n-7 FA is known to be derived from food and used as a source of energy (Tocher 2003). The content of this acid was higher in the TAG (6.2\%-7.1\% of the total FA) than in PL (2.0\%-5.0\% of the total FA). Most of the dietary FA are incorporated into TAG, unaltered (Sargent et al.2002; Iverson 2009).

Thus, high levels of 20:1n-9 and 22:1n-11, as well as 16:1n-7 FA in the TAG of the lipid sac of postlarvae of the L3, L4, and L4* stages confirm feeding on Calanus spp., both in the pelagic zone and near the bottom during the polar night. A rise from $23.6 \%$ to $60.6 \%$ of the total FA was demonstrated for the MUFA content in the PL is due to the increase in $20: 1 \mathrm{n}-9$ and 22:1n-11 FA (from $9.7 \%$ to $24.8 \%$, and from $7.7 \%$ to $20.4 \%$ of the total FA, respectively. The FA composition of food items of fish is known to influence to involvement of individual FA in the adaptive transformation of the organism's biomembranes in response to the environmental and food (Dalsgaard et al. 2003; Arts and Kohler 2009; Tocher 2010; Murzina et al. 2012b; Nemova et al. 2015). It has been suggested that increase hydrostatic pressure and low temperature effect the biomembrane (Velansky and Kostetsky 2008) as shown with the increase of MUFA with depth. In our previous research, we found that the MUFA/PUFA content in the TL is higher in the arctic L. maculatus (Fries 1838) (Isfjord, Spitzbergen) inhabiting at $0^{\circ} \mathrm{C}$ temperatures at $206 \mathrm{~m}$ compared with the subarctic Lumpenus fabricii (Reinhardt 1836) (White Sea) collected from two habitats in the temperature range of $5.9-6.7^{\circ} \mathrm{C}$ at depths down to $38 \mathrm{~m}$ (Murzina et al. 2013). Despite the known genetic determinacy, the FA composition of the PL may vary at early ontogenetic stages in fish in response to environmental factors (Tocher et al. 2008). The high dietary supply of 20:1n-9 and 22:1n-11 FA deposited in the lipid sac of daubed shanny can influence the FA composition of the PL, which are involved in the adaptation of biomembranes to extreme environments. A decrease (two-fold) of the SFA content in the PL (58.1\%-26\% of the total FA) in the lipid sac was detected, possibly due to a demand for a modification of the fatty acid composition. This implies a replacement of SFA with MUFA in the biomembranes in the ontogenetic transition from L3 to L4* to a demersal stage of life.

The content of PUFA is 2.5 - fold lower in the PL and seven - folds lower in the TAG of the lipid sacs compared to the MUFA content. The PUFA content in the PL is considerably lower in the lipid sac (up to $18.7 \%$ of 
al. 2019), suggesting that they have a major role in maintaining the functioning of complex biomembranes. Polyunsaturated fatty acids of the n-3 class were found to prevail over n-6 PUFA in the PL and TAG in the lipid sac.

Very low level of 18:2n-6 and 18:3n-3 FA in the PL and TAG in the lipid sac $(\leq 2.3 \%$ of all FA in the total lipids) was observed. However, moderate to low levels of 22:6n-3, 20:5n-3, and 18:4n-3 prevailed, which is typical of marine organisms at high latitudes (Sargent et al. 2002; Burri et al. 2012; Mayzaud et al. 2015), who derive the FA from their food. The PL were dominated by 22:6n-3 (up to 4.6\%), and the TAG by 18:4n-3 (up to 2.0\%). The 22:6n-3, 20:5n-3 FA are known to be essential for marine predaceous fish and are supplied in large amounts in food, whereas 18:2n-6 and 18:3n-3 FA are less important for growth and development. Marine fish have low capacity to convert these FA into highly unsaturated FA (Sargent et al. 1995; Tocher 2003).

\section{Conclusions}

We present, for the first time, data on the FA composition of the membranes and storage lipids in the lipid sac of the postlarvae stages (L3, L4 and L4*), of the daubed shanny from the polar night. A distinctive feature of the FA profile of the lipid sac in young fish of the daubed shanny is that the TAG and PL contain high levels of the MUFA, primarily 20:1n-9 and 22:1n-11 FA, which are biomarkers of the zooplankton Calanus spp.. The high content of these FA in the daubed shanny larvae indicate that Calanus copepods are the main food source for juveniles during the polar night. These data are important for the analysis of the putative pathways of the FA transformations and transfer in the food web of the Arctic ecosystem. Data on the fatty acid composition of the TAG and PL in the lipid sac of postlarvae daubed shanny developing under polar night conditions can contribute to the understanding of the role of lipids in the early ontogenetic ecological-biochemical adaptations of this Arctic fish species whose life cycle has, so far, been poorly studied.

214 Acknowledgements: The research was conducted within the framework of the state assignment of the KarRC RAS 215 No. 0218-2019-0076, MK-2188.2020.4 and the Norwegian Research Council projects Timing of ecological 216 processes in Spitsbergen fjords SpitsEco (ES504895) and ArcticABC (No 244319).

\section{Compliance with Ethical Standards}

219 The authors declare no conflict of interest and that all applicable institutional, national or international guidelines for 220 the use and care of animals were strictly followed in the present study.

221 Conflict of interest: The authors declare no conflicts of interest.

\section{References}

Arts MT, Kohler CC (2009) Health and conditions in fish: the influence of lipids on membrane competency and immune response. In: Arts MT, Brett MT, Kainz MJ (eds) Lipids in Aquatic ecosystems. Springer, New York, pp 237-257

Berge J, Daase M, Renaud PE et al (2015a) Unexpected Levels of Biological Activity during the Polar Night Offer

Barrett RT (2002) Atlantic puffin Fratercula arctica and common guillemot Uria aalge chick diet and growth as indicators of fish stocks in the Barents Sea. Mar Ecol Prog Ser 230:275-287. https://www.intres.com/articles/meps2002/230/m230p275.pdf New Perspectives on a Warming Arctic. Curr Biol 25:2555-2561. https://www.cell.com/currentbiology/fulltext/S0960-9822(15)00995-1 Berge J, Renaud PE, Darnis G, Cottier F, Last KS, Gabrielsen 

OJ, Daase M, Falk-Petersen S. (2015b) In the dark: A review of ecosystem processes during the Arctic polar night. Prog Oceanogr 139:258-271. https://www.sciencedirect.com/science/article/pii/S0079661115001858?via\%3Dihub

Burri L, Hoem N, Banni S, Berge K (2012) Marine Omega-3 Phospholipids: Metabolism and Biological Activities. Int. J. Mol. Sci. 13:15401-15419. https://doi.org/10.3390/ijms131115401

Dalsgaard J, St John M, Kattner G, Muller-Navarra D, Hagen W (2003) Fatty acid trophic markers in the pelagic marine environment. Adv Mar Biol 46:225-340. https://doi.org/10.1016/S0065-2881(03)46005-7

Eastman JT, DeVries AL (1989) Ultrastructure of the Lipid Sac Wall in the Antarctic Notothenioid Fish Pleurogramma antarcticum. Polar Biol 9:333-335. https://link.springer.com/article/10.1007/BF00287433

Engelbrecht F M., Mari F, Anderson JT (1974) Cholesterol determination in serum. A rapid direction method. S. A. Med. J. 48:250-356

Falk-Petersen S, Falk-Petersen I-B, Sargent JR (1986) Structure and function of an unusal lipid storage organ in the Arctic fish lumpenus maculatus $\quad$ Fries, $1838 . \quad$ Sarsia https://doi.org/10.1080/00364827.1986.10419666Falk-Petersen S, Haug T, Nilsen KT, Wold A, Dahl TM (2004) Lipids and trophic linkages in harp seal (Phoca groenlandica) from the eastern Barents Sea. Polar Res 23:43-50. https://doi.org/10.1111/j.1751-8369.2004.tb00128.x

Falk-Petersen S, Timofeev S, Pavlov V, Sargent JR (2007) Climate variability and possible effects on arctic food chains: The role of Calanus. In: Ørbæk JB,Tombre T, Kallenborn R, Hegseth E, Falk-Petersen S, Hoel AH (eds) Arctic Alpine Ecosystems and People in a Changing Environment. Springer Verlag, Berlin, pp 147166Falk-Petersen S, Mayzaud P, Kattner G, Sargent JR (2009) Lipids and life strategy of Arctic Calanus. Mar Biol Res 5:18-39. https://doi.org/10.1080/17451000802512267

Folch J, Lees M, Sloan-Stanley GH (1957) A simple method for the isolation and purification of total lipids animal tissue (for brain, liver and muscle). J Biol Chem 226:497-509.

Hop H, Falk-Petersen S, Svendsen H, Kwasniewski S, Pavlov V, Pavlova O, Soreide JE (2006) Physical and biological characteristics of the pelagic system across Fram Strait to Kongsfjorden. Prog Oceanogr 71:182231.

https://doi.org/10.1016/j.pocean.2006.09.007Hovde SC, Albert OT, Nilssen EM (2002) Spatial, seasonal and ontogenetic variation in diet of Northeast Arctic Greenland halibut (Reinhardtius hippoglossoides). ICES J Mar Sci 9:421-437. https://doi.org/10.1006/jmsc.2002.1171

Iverson SJ (2009) Tracing aquatic food webs using fatty acids: from qualitative indicators to quantitative determination. In: Arts MT, Brett MT, Kainz MJ (eds) Lipids in Aquatic Ecosystems. Springer, New York, pp 281-307.

Jamieson GR (1975) GLC-identification techniques for long chain unsaturated fatty acids. J Chromatogr Sci 13:491497.

Kattner G, Hagen W (1995) Polar herbivorous copepods - different pathways in lipid biosynthesis. ICES J Mar Sci 52:329-335. https://doi.org/10.1016/1054-3139(95)80048-4

Kwasniewski S, Hop H, Falk-Petersen S, Pedersen G (2003) Distribution of Calanus species in Kongsfjorden, a glacial fjord in Svalbard. J Plankton Res 25:1-20. https://doi.org/10.1093/plankt/25.1.1

Labansen AL, Lydersen C, Haug T, Kovacs KM (2007) Spring diet of ringed seals (Phoca hispida) from northwestern Spitsbergen, Norway. ICES J Mar Sci 64:1246-1256. https://doi.org/10.1093/icesjms/fsm090 
Lee R, Hagen W, Kattner G (2006) Lipid storage in marine zooplankton. Mar Ecol Prog Ser 307:273-306. https://doi.org/10.3354/meps307273

Lloret J, Shulman G, Malcolm LR (2014) Conditions and health indicators of exploited marine fish. Wiley Blackwell, Oxford

Makushok VM (1979) LumpenidaeIn: Hureau JC, Monod Th (eds) Check-list of the fishes of the north-eastern Atlantic and of the Mediterranean (CLOFNAM). UNESCO, Paris, pp 536-539

Mayzaud P, Falk-Petersen S, Noyon M, Wold A, Boutoute M (2015) Lipid composition of the three co-existing Calanus species in the Arctic: impact of season, location and environment. Polar Biol 39:1819-1839. https://link.springer.com/article/10.1007/s00300-015-1725-9

Mecklenburg CW, Møller PR, Steinke D (2011) Biodiversity of arctic marine fishes: taxonomy and zoogeography. Mar Biodivers 41:109-140. https://doi.org/10.1007/s12526-010-0070-zMeyer Ottesen CA, Haakon H, Christiansen JS, Falk-Petersen S (2011) Early life history of the daubed shanny (Teleostei: Lepticlinus maculatus) in Svalbard waters. Mar Biodivers 41:383-394. https://link.springer.com/content/pdf/10.1007\%2Fs12526-010-0079-3.pdf

Meyer Ottesen CA, Haakon H, Falk-Petersen S, Christiansen JS (2014) Growth of daubed shanny (Teleostei: Leptoclinus maculatus) in Svalbard waters. Polar Biol37:809-815. https://www.academia.edu/8125124

Meyer Ottesen CA, Haakon H, Falk-Petersen S, Christiansen JS (2018) Reproduction and sexual dimorphism of daubed shanny (Teleostei: Leptoclinus maculatus) in Svalbard waters. Polar Biol 41:1867-1880. https://doi.org/10.1007/s00300-018-2328-z

Murzina SA (2010) The role of lipids and their fatty acid components in the biochemical adaptations of the daubed shanny Leptoclinus maculatus F. of the northwestern coast of. Svalbard. Dissertation, IB KarRC RAS

Murzina SA, Meyer Ottesen CA, Falk-Petersen S, Hop H, Nemova NN, Polyektova OG (2012a) Oogenesis and lipids in gonad and liver of daubed shanny (Leptoclinus maculatus) females from Svalbard waters. Fish Physiol Biochem 38:1393-1407. https://doi.org/10.1007/s10695-012-9627-z

Murzina SA, Nefedova ZA, Nemova NN (2012b) Influence of fatty acids (markers of food sources of fish) on mechanisms of adaptation in high latitudes (Review). Proceedings of the Karelian Scientific Center of the RAS 2:18-25.

Murzina AS, Nefedova ZA, Falk-Petersen S, Hop H (2013) Lipids in the daubed shanny (Teleostei: Leptoclinus maculatus) in Svalbard waters. Polar Biol 36:1619-1631. https://ink.springer.com/article/10.1007/s00300013-1381-x

Nemova NN, Nefedova ZA, Murzina SA, Veselov AE, Ripatti PO, Pavlov DS (2015) The effect of environmental conditions on the dynamics of fatty acids in juveniles of the Atlantic salmon (Salmo salar L.). Rus J Ecol 46:267-271. https://link.springer.com/article/10.1134\%2FS106741361503008X

Pekkoeva SN, Murzina SA, Nefedova ZA, Ripatti PO, Falk-Petersen S, Berge J, Lonne O, Nemova NN (2017a) Ecological Role of Lipids and Fatty Acids in the Early Postembryonic Development of the Daubed Shanny, Leptoclinus maculatus (Fries, 1838) from Kongsfjord, West Spitsbergen in Winter. Rus J Ecol 48:240-244. https://link.springer.com/article/10.1134/S1067413617030134

Pekkoeva SN, Murzina SA, Nefedova ZA, Ruokolainen TR, Falk-Petersen S, Berge J, Lonne OJ, Nemova N.N. (2017b) Role of Phospholipids in Early Ontogenesis of Arctic-Boreal Species Leptoclinus maculatus (Stichaeidae). Journal of Ichthyology 57(4):625-629. https://doi.org/10.7868/S0042875217040129 Ecological Groups of the Daubed Shanny Leptoclinus maculatus (Fries, 1838), an Arcto-boreal Species, 

https://doi.org/10.7868/S0367059718030083

Pekkoeva SN, Murzina SA, Nefedova ZA, Falk-Petersen S, Berge J., Lonne OJ, Nemova NN (2019) Fatty Acid Content of Structural and Storage Lipids in Muscles of the Daubed Shanny Postlarvae Leptoclinus maculatus (Fries, 1838) from Kongsfjord (Svalbard Archipelago). J EvolBiochem Phys 55:104-111. https://link.springer.com/article/10.1134/S0022093019020030

Sargent JR, Bell JG, Bell MV, Henderson RJ, Tocher DR (1995) Dietary origins and functions of longchain (n-3) polyunsaturated fatty acids in marine fish. Journal of Marine Biotechnology 3:26-28.

Sargent JR, Henderson RJ (1986) Lipids. In: Corner EDS, O’Hara SCM (eds) The biological chemistry of marine copepods. Clarendon Press, Oxford, pp. 59-164.

Sargent JR, Tocher DR, Bell JG (2002) The lipids. In: Halver JE, Hardy RW (eds) Fish Nutrition. Academic Press, San Diego, CA, USA, pp 181-257

Sidorov VS, Lizenko EI, Bolgova OM, Nefedova ZA (1972) Lipids of fish. 1. Methods of analysis. Tissue specificity of vendace Coregonus albula L. In: Salmonids (Salmonidae) of Karelia. Karel. Phil. USSR Academy of Sciences, Petrozavodsk, pp 152-163

Søreide JE, Hop H, Carroll ML, Falk-Petersen S, Hegseth EN (2006) Seasonal food web structures and sympagicpelagic coupling in the European Arctic revealed by stable isotopes and a two-source food web model. Prog Oceanogra 71: 59-87. http://mariclim.npolar.no/papers-and-publications/soreide-et-al-2006.pdf

Swanburg T., Horne J.B., Baillie S. et al. (2015) Complete mitochondrial genomes for Icelus spatula, Aspidophoroides olrikii and Leptoclinus maculatus: pan-Arctic marine fishes from Canadian waters. Mitochondrial DNA. 1940-1744. https://doi.org/10.3109/19401736.2015.1060472

Tocher DR, Fraser AJ, Sargent JR, Gamble JC (1985) Lipid class composition during embryonic and early larval development in Atlantic herring (Clupea harengus L.). Lipids 20:84-89.

Tocher DR (2003) Metabolism and functions of lipids and fatty acids in teleost fish. Revi Fish Sci11:107-184. https://doi.org/10.1080/713610925

Tocher DR (2010) Fatty acid requirements in ontogeny of marine and freshwater fish. Aquac Res 41:717-732. https://doi.org/10.1111/j.1365-2109.2008.02150.x

Tocher DR, Bendiksen E, Campbell P, Bell J (2008) The role of phospholipids in nutrition and metabolism of Teleost fish. Aquaculture 280:21-34. doi: 10.1016/j.aquaculture.2008.04.034

Weslawski JM, Kwasniewski S, Stempniewicz L, Beachowiak-Samolyk K (2006) Biodiversity and energy transfer to top trophic levels in two contrasting Arctic fjords. Pol Polar Res 27(3):259-278. https://www.researchgate.net/profile/Lech_Stempniewicz/publication/232724097

Walsh DE, Banasik OJ, Gilles KA (1965) Thin-layer chromatographic separation and colorimetric analysis of barley or malt lipid classes and their fatty acids. Chromatography17(2): 78-85.

List of table and figure captions

350 Table 1 Data of sampling of the Leptoclinus maculatus postlarvae in Kongsfjord (Svalbard)

351 Table 2 The content of lipid classes (\% of dry weight) in the lipid sac of postlarvae Leptoclinus maculatus of different developmental stages (L3, L4, L4 *) from Kongsfjord. c - the value significantly differs from that of stage L3 ( $p \leq 0.05), d-$ the value significantly differs from that of stage $L 4(p \leq 0.05)$. Table 3 The content of some fatty acids in the composition of phospholipids and triacylglycerols in the lipid sac of the daubed shanny postlarvae. SFA - saturated fatty acids; MUFA - monounsaturated fatty acids; PUFA - polyunsaturated 
357 acids, the values of that did not exceed 1\%: 12:0; 15:0; 17:0; 20:0; 24:0; 16:1(n-5); 18:1(n-5); 22:4(n-6); 22:3(n-3);

$358 \quad 22: 4(n-3)$ FA.

359 Fig 1 Leptoclinus maculatus early life stages (L1, L2, L3, L4, L4*, L5) (Pekkoeva et al., 2018).

360 Fig 2 Map of sampling of the Leptoclinus maculatus postlarvae in fjords (Kongsfjord) west coast of Svalbard $\left(79^{\circ} \mathrm{N}\right)$

361 (Google Earth)

362

363 
Table 1 Data of sampling of the Leptoclinus maculatus postlarvae in Kongsfjord (Svalbard)

\begin{tabular}{|c|c|c|c|c|c|c|}
\hline Stage & L1 & L2 & L3 & L4 & $\mathrm{L} 4 *$ & L5 \\
\hline Samples & 6 & 30 & 40 & 30 & 12 & 17 \\
\hline $\begin{array}{l}\text { Length, cm } \\
\text { (Pekkoeva et al., 2018) }\end{array}$ & 3.4 & 5.8 & 6.5 & 7.5 & 8.9 & 9.0 \\
\hline Equipment & MIK net & \multicolumn{3}{|c|}{ Pelagic trawl } & \multicolumn{2}{|c|}{ Bottom trawl } \\
\hline Depth of sampling, m & 30 & \multicolumn{3}{|c|}{125} & \multicolumn{2}{|r|}{$>130$} \\
\hline Temperature, ${ }^{\circ} \mathrm{C}$ & $0.60-1.90$ & \multicolumn{3}{|c|}{$0.90-1.10$} & \multicolumn{2}{|c|}{$0.60-0.80$} \\
\hline Salinity, psu & 34.8 & \multicolumn{3}{|c|}{34.8} & \multicolumn{2}{|c|}{$34.7-34.8$} \\
\hline
\end{tabular}

365

366 
Table 2 The content of lipid classes (\% of dry weight) in the lipid sac of postlarvae Leptoclinus maculatus of different developmental stages (L3, L4, L4 *) from Kongsfjord. c - the value significantly differs from that of stage L3 ( $p \leq 0.05), d-$ the value significantly differs from that of stage L4 ( $p \leq 0.05)$.

370

371

372

373

374

375

376

377

\begin{tabular}{|l|c|c|c|}
\hline Stage of development & L3 & L4 & L4 $^{*}$ \\
\hline Total lipids & $75.97 \pm 2.79$ & $84.63 \pm 1.92^{\mathrm{c}}$ & $92.32 \pm 0.82^{\mathrm{cd}}$ \\
\hline Dry mass & $24.03 \pm 2.79$ & $15.37 \pm 1.92^{\mathrm{c}}$ & $7.68 \pm 0.82^{\mathrm{cd}}$ \\
\hline Total lipids / Dry mass & 3.16 & 5.51 & 12.02 \\
\hline \multicolumn{2}{|c|}{ Structural lipids } \\
\hline Phospholipids & $0.84 \pm 0.31$ & $13.11 \pm 4.78^{\mathrm{c}}$ & $31.01 \pm 5.36^{\mathrm{cd}}$ \\
\hline Cholesterol & $3.42 \pm 0.35$ & $11.31 \pm 4.36^{\mathrm{c}}$ & $4.37 \pm 0.89^{\mathrm{d}}$ \\
\hline \multicolumn{4}{|c|}{ Energetic lipids } \\
\hline Triacylglycerols & $68.75 \pm 2.47$ & $55.15 \pm 5.83^{\mathrm{c}}$ & $55.95 \pm 5.76^{\mathrm{c}}$ \\
\hline $\begin{array}{l}\text { Cholesterol esters and wax } \\
\text { esters }\end{array}$ & $2.96 \pm 0.42$ & $4.06 \pm 1.09$ & $1.01 \pm 0.30^{\mathrm{cd}}$ \\
\hline
\end{tabular}

Table 3 The content of some fatty acids in the composition of phospholipids and triacylglycerols in the lipid sac of the daubed shanny postlarvae. Abbreviations: SFA - saturated fatty acids; MUFA - monounsaturated fatty acids; PUFA - polyunsaturated fatty acids. $\mathrm{c}$ - the value significantly differs from that of stage L3 ( $p \leq 0.05)$. The samples contained other fatty acids, the values of that did not exceed 1\%: 12:0; 15:0; 17:0; 20:0; 24:0; 16:1(n-5); 18:1(n-5); 22:4(n-6); 22:3(n-3); 22:4(n-3) FA.

Phospholipids

L3

L4

L4*

L3

L4

L4*

14:0

$2.6 \pm 0.2$

$5.5 \pm 1.0$

$6.6 \pm 0.5^{c}$

$7.0 \pm 0.1$

$6.5 \pm 0.4$

$6.0 \pm 0.2$

16:0

$13.2 \pm 0.9$

$11.2 \pm 1.0$

$9.9 \pm 0.2^{\mathrm{c}}$

$8.2 \pm 0.2$

$7.7 \pm 0.4$

$7.5 \pm 0.1$

18:0

$$
6.7 \pm 03
$$

$3.3 \pm 0.6$

$2.1 \pm 0.2$

$0.9 \pm 0.1$

$0.7 \pm 01$

$0.8 \pm 0.0$

$\sum$ SFA

$58.1 \pm 2.7$

$31.6 \pm 2.7^{c}$

$25.9 \pm 1.4^{c}$

$18.9 \pm 0.4$

$16.7 \pm 1.0$

$16.2 \pm 0.4^{\mathrm{c}}$

16:1n-7

$2.0 \pm 0.2$

$3.5 \pm 0.4$

$5.0 \pm 0.3$

$6.2 \pm 0.2$

$6.4 \pm 0.2$

$7.1 \pm 0.2$

18:1n-9

$4.7 \pm 0.3$

$4.5 \pm 0.3$

$4.1 \pm 0.1$

$5.3 \pm 0.1$

$4.6 \pm 0.3$

4. $6 \pm 0.1$

20:1n-9

$9.7 \pm 0.8$

$19.4 \pm 3.1$

$24.8 \pm 1.4^{c}$

$27.5 \pm 0.2$

$28.0 \pm 0.4$

$28.2 \pm 0.3$

22:1n-11

$7.7 \pm 0.7$

$16.5 \pm 2.7$

$20.4 \pm 1.5$

$26.9 \pm 0.6$

$29.3 \pm 0.7$

$27.8 \pm 0.7$

$\sum$ MUFA

$26.3 \pm 1.9$

$49.7 \pm 6.3^{c}$

$60.6 \pm 3.3^{c}$

$70.7 \pm 0.6$

$73.7 \pm 0.4$

$73.1 \pm 1.0$

18:2n-6

$2.3 \pm 0.1$

$1.8 \pm 0.3$

$1.4 \pm 0.2$

$2.2 \pm 0.1$

$1.9 \pm 0.1$

$1.9 \pm 0.1$

20:4n-6

$0.1 \pm 0.0$

$0.3 \pm 0.1$

$0.1 \pm 0.0$

$0.1 \pm 0.0$

$0.1 \pm 0.0$

$0.1 \pm 0.0$

$\sum n-6$ PUFA

$2.3 \pm 0.1$

$5.1 \pm 1.1$

$3.4 \pm 0.5$

$3.0 \pm 0.2$

$2.6 \pm 0.1$

$2.7 \pm 0.1$

18:3n-3

$0.4 \pm 0.1$

$0.2 \pm 0.0$

$0.2 \pm 0.0$

$0.8 \pm 0.0$

$0.5 \pm 0.1$

$0.5 \pm 0.1$ 


\begin{tabular}{|c|c|c|c|c|c|c|}
\hline $18: 4 n-3$ & $0.8 \pm 0.1$ & $0.5 \pm 0.1$ & $0.7 \pm 0.1$ & $1.9 \pm 0.1$ & $1.7 \pm 0.4$ & $2.0 \pm 0.4$ \\
\hline $20: 5 n-3$ & $1.5 \pm 0.4$ & $0.8 \pm 0.3$ & $0.5 \pm 0.1$ & $1.0 \pm 0.1$ & $0.7 \pm 0.2$ & $1.0 \pm 0.3$ \\
\hline $22: 6 n-3$ & $4.6 \pm 0.5$ & $2.8 \pm 0.4$ & $2.0 \pm 0.2$ & $1.6 \pm 0.1$ & $1.3 \pm 0.2$ & $1.5 \pm 0.3$ \\
\hline$\sum n-3$ PUFA & $7.7 \pm 0.9$ & $6.3 \pm 1.1$ & $4.6 \pm 0.6^{\mathrm{c}}$ & $5.8 \pm 0.3$ & $4.8 \pm 0.7$ & $5.7 \pm 1.2$ \\
\hline$\sum$ PUFA & $15.6 \pm 1.1$ & $18.7 \pm 3.6$ & $13.5 \pm 1.9$ & $10.4 \pm 0.5$ & $9.7 \pm 0.6$ & $10.7 \pm 1.3$ \\
\hline$\sum n-3 / \sum n-6$ & $3.4 \pm 0.3$ & $1.3 \pm 0.1$ & $1.4 \pm 0.1$ & $2.0 \pm 0.1$ & $1.8 \pm 0.3$ & $2.0 \pm 0.4$ \\
\hline$\sum \mathrm{SFA} / \sum \mathrm{PUFA}$ & 3.7 & $1.7^{\mathrm{c}}$ & $1.9^{c}$ & 1.8 & 1.7 & 1.5 \\
\hline $18: 3 n-3 / 18: 2 n-6$ & 0.2 & 0.1 & 0.1 & 0.3 & 0.2 & 0.3 \\
\hline $16: 0 / 18: 1 n-9$ & 2.8 & 2.4 & 2.4 & 1.6 & 1.7 & 1.6 \\
\hline
\end{tabular}

378 
$381 \quad$ Fig 1

Total length, cm

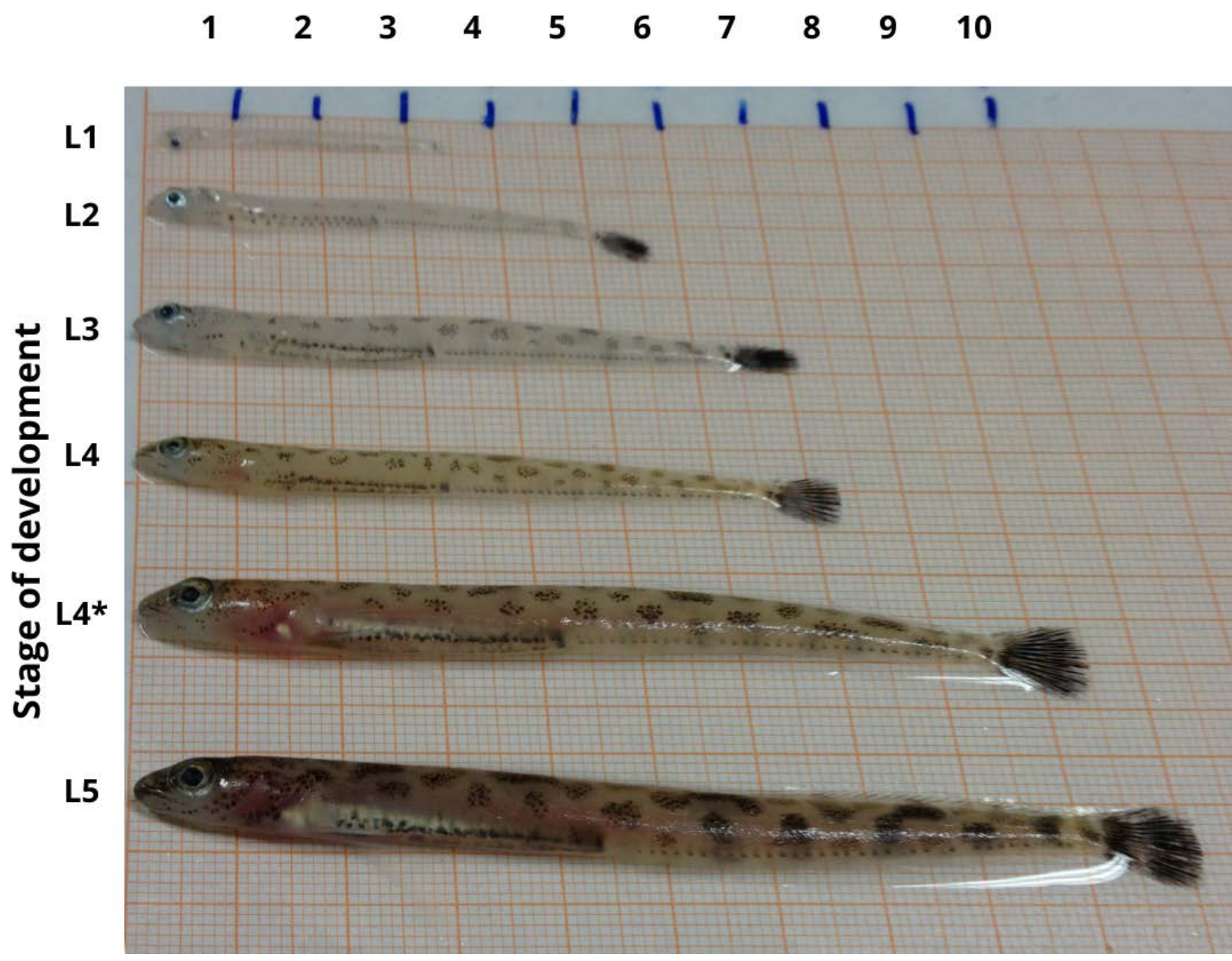

383 
Fig 2

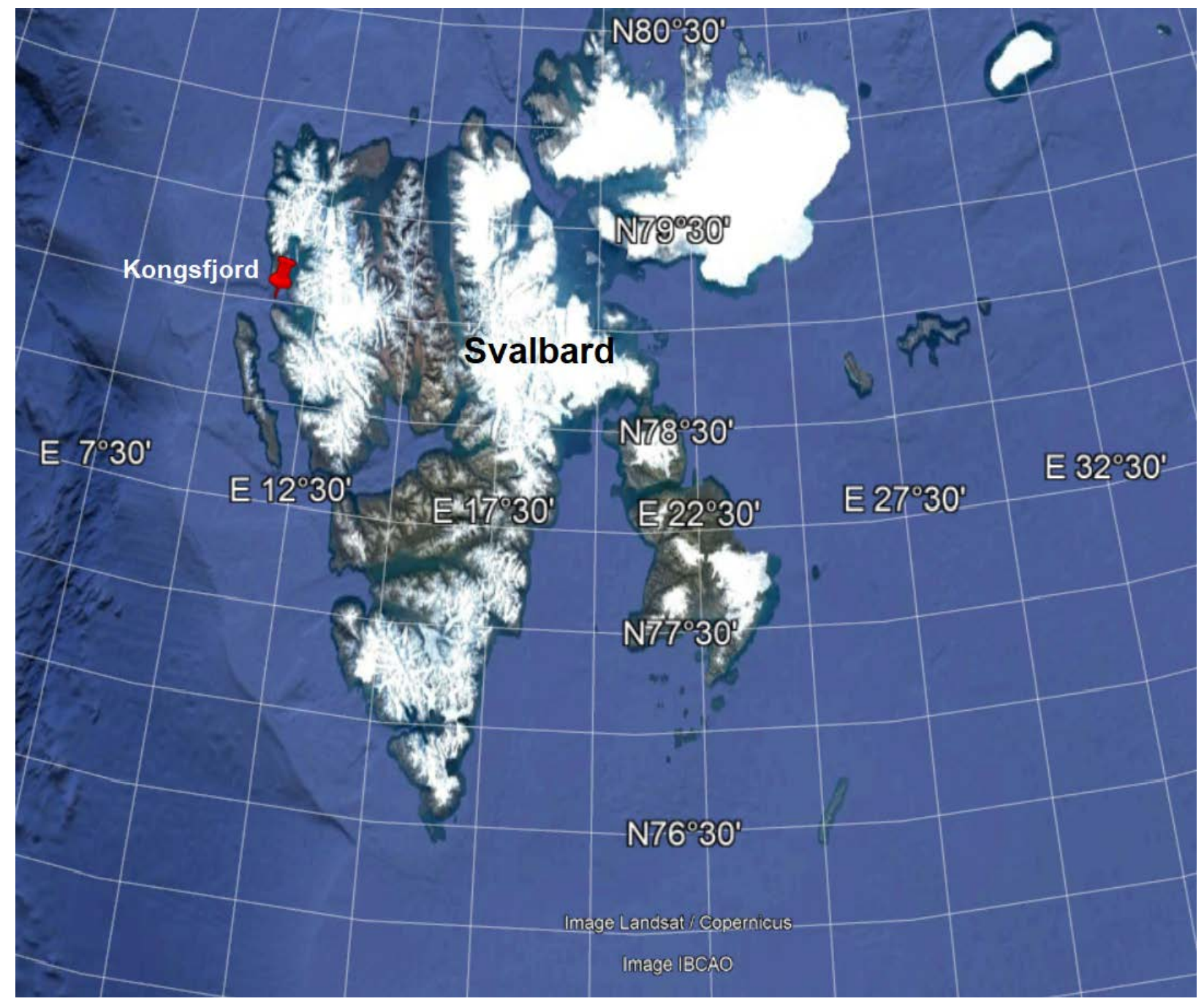

